\title{
Evaluating the Sustainability of mHealth Systems in Developing Countries: the Knowledge Gap
}

\author{
Muhambe Titus Mukisa ${ }^{1}$, Daniel Orwa Ochieng ${ }^{2}$, Peter Wagacha Waiganjo ${ }^{3}$ \\ School of Computing \& Informatics Maseno University, Kenya \\ School of Computing \&Informatics, University of Nairobi, Kenya
}

\begin{abstract}
The use of mobile technology in healthcare, known as mHealth is being explored across the developing countries as part of the effort to tackle growing disease burden through, prevention and appropriate and prompt intervention strategies. Although the outcomes of some of the implemented mHealth projects have been successful with very promising results, a significant number of the projects have failed after a short period of use. Studies carried out on the failed projects pointed to lack of sustainability. Review of existing technology evaluation model against the cited challenges reveals significant deficiencies in the models and thus not suitable to evaluate sustainability of mHealth system in developing countries. It is clear that there exist a knowledge gap and hence the need to develop and validate a suitable mHealth system sustainability evaluation model.
\end{abstract}

Keywords: Evaluation, mHealth, Model, Sustainability

\section{Introduction}

The health sectors in developing countries face multiple challenges and as such there have been challenges in tackling the growing disease burden. World Health Organization reporton global morbidity and mortality rates indicates that a significant number of deaths in developing countries result from easily preventable diseases. The continued growth of disease burden in developing countries has and continues to have profound negative impact on the quality of life and the economy[1]. There are many ongoing initiatives and efforts to tackle the disease burden including the use of Information Communication Technology [2, 3]. One of the technologies that have been exploited is the use of mobile technology also known as mHealth; a medical and public health practice supported by mobile devices, such as mobile phones, patient monitoring devices, personal digital assistants (PDAs), and other wireless devices[2, 3]. The efforts aim at exploiting potential presented by mobile technologies, towards prevention and intervention in tackling the disease burden challenge. Despite the enormous potential, utilization of mHealth initiatives and innovations faces multiple challenges and obstacles that need to be urgently tackled if the benefits of this strategy have to be realized.

\section{Literature Review}

\section{1 mHealth Application Areas}

Multiple studies have identified the mHealth application areas [2, 3, 4, 5, 6,7];

- Appointment and Medication reminder; a system that enables sending of alerts or reminders to patients using mobile phones. The reminder alerts are aimed at reminding a patient to take medication at recommended times or to honour doctor appointments. The overall aim of this type of solution is to enhance the level of the patient's adherence to medication and treatment regime.
- E-prescribing for repeat prescriptions: a tool that enables a patient to make requests and gets prescription a medical practitioner over the mobile phone using text messages.

- Remote monitoring of patients conditions; a system that monitors and reports on patient's current status; reports on patient's blood pressure, temperature and pulse rate. This is achieved using mobile devices and sensor attached to the patient's body.

- Transmission of test results to patients; aimed at providing some level of convenience to the patient by lowering the cost of travelling to the healthcare facility by a patient to collect test results. Using the results transmitted in the form of text, the patient can seek medication at the nearest healthcare facility.

- Clinical advice; tool or solution enables automated clinical tips of specific health issues. A customer sends a text message to a specific known number, where the system automatically generates responses depending on the user request.

- Data Collection and surveillance; mainly utilized by community health workers or epidemic/disease surveillance field personnel, to collect and submit health indicators and disease occurrence data to a central repository via mobile phone SMS or custom made mobile phone applications.

- Linking Community Health Workers $(\mathrm{CHW})$ or Community nurses in remote areas with clinical expert; the solutioncreates a channel of communication between community health workers or community nurses working in remote regions and a clinician expert and allows for consultation and advices on complex medical cases.

- Public health and lifestyle promotional messages - used as a public awareness platform that enables dissemination of information via Short Text Messages, that aim at promoting health living and good public health. Mostly used in national health campaign programmes.

\section{2 mHealth Systems Sustainability Challenge}

Although many mHealth projects have shown potential to aid in the tackling of disease burden, reports indicate that a 


\section{International Journal of Science and Research (IJSR) \\ ISSN (Online): 2319-7064}

Index Copernicus Value (2015): 78.96 | Impact Factor (2015): 6.391

significant number of mHealth solutions deployed in the developing countries have failed. A number of reasons are cited but when summed up, these reasons points to sustainability challenges. Various studies [8, 9, 10, 11] highlight reasons why some of the mHealth projects failed; factors relating to users include user dissatisfaction with the deployed systems, insufficient user support; lack of or insufficient technical expertise and manpower to provide the much needed user support, System access challenges; inability of users to gain access to the mHealth system especially where there is cost element associated with using the system, lack of appropriate mobile gadgets, lack of power to recharge the gadgets especially in remote locations of developing countries and limited or poor network connectivity and coverage. Some of the technological factors cited as possible causes of failure of the mHealth projects in developing countries include relevance challenges; mismatch between technological features in the mHealth solution and tasks or healthcare needs of the locality where the project is implemented. The technology is designed elsewhere and deployed without considering the social technical issues of the locality where the mHealth technology would be deployed. Other technological challenges cited include; inability of the solution to scale, inability of the mHealth system to interface and interoperate with existing healthcare systems and poor system quality. The management and administration aspects cited as possible contributors to failure of mHealth projects include; challenges in strategy and planning, lack of sustainable financial resources and challenges in the governance of mHealth systems.

\subsection{Evaluating mHealth Sustainability}

Design, Implementation and maintenance of the mHealth solutions consume valuable yet scarce resources. Failed mHealth projects leads to wastage of the scarce resources and in addition, slows down of the fight against the growing disease burden. There is therefore a need to ensure that the implemented mHealth solutions are sustainable; ability of the deployed solutions to meet current needs without compromising on the ability of the same system to meet future needs, even when the environment and the dynamics change [12]. Structured evaluation of the sustainability of a solution requires a tested and validated guiding model.

Evaluation of sustainability of a technology solution is a post-implementation activity that focuses on assessing overall system effectiveness while in operation as well as the ability of the technology solution to realize the current objectives, goals and user needs as well as the objectives, goals and user needs in the future. The eco-system within which the system operates is defined and influenced by; users factors, management practices and the technology factors and therefore, evaluation of sustainability of a technology artefact must considerand include applicable aspects of all these factors[13].

\subsection{Social-Technical Models}

Technology has been applied in almost all spheres of life. The application of technology is aimed at ensuring efficiency and effectiveness in the process of accomplishing of the objectives and goals associated with a certain task or activity. Successful utilization of technology in an enterprise involves complex social-technical relationships and interactions that influences the acceptance, adoption, implementation and sustainable utilization of technology. Social-technical thinking has been supported [13] by the arguments that human principle plays a significant role in defining how a technology is accepted and utilized. It is argued that evaluation of health information system is challenging and difficult to perform in particular, selecting appropriate framework and methods to use happens to be the most challenging part [14]. The success of any technological innovation in terms of acceptance, adoption, implementation and sustainable utilization, depends on the level of understanding of the social technical forces that define the utilization environment. Proponents of social-technical thinking have strongly argued that it should positively influences a technology designer to deliberately enhance the quality of working life of a user in order to guarantee job satisfaction and hence positively influence adoption, utilization, outcomes and sustainability of the technology $[15,16,17]$.

The social-technical thinking school of thought has it that three key paradigms must be understood and considered when understanding the design, deployment, acceptance, adoption, utilization and sustainability of technology [18, 19, 20]. These are; technical, social and environmental paradigms. The technical aspects of a technology cover the tools and devices that make up the technology and techniques utilized when converting given inputs into desired outputs. The social components on the other hand covers knowledge and skills of users, the attitudes of the users towards the technology artefact, expected value outcomes and the unique personal needs that must be addressed by the environment that they find themselves working in. Finally, the environmental paradigm includes governance, management and authority structures defined within the organization, policies and regulations that govern activities and interaction relating to the deployed technology in the organization $[15,17]$.

It is therefore necessary to review existing social-technical models and assess their suitability in evaluating sustainability of technology.

\subsection{Technology Evaluation Models}

Several technology evaluation models have been developed, tested and validated in various contexts. Existing technology evaluation models have been here analysed in light of the failure of mHealth projects in developing countries. The table below shows a summary of the key models for evaluation of technology.

Table 1: Summary of Evaluation Models

\begin{tabular}{|c|c|}
\hline Model & $\begin{array}{c}\text { Targeted System/Component of } \\
\text { Evaluation }\end{array}$ \\
\hline $\begin{array}{c}\text { Task Technology Fit } \\
\text { Model [21] }\end{array}$ & $\begin{array}{c}\text { Designed for evaluating the degree to } \\
\text { which technology artefact feature map } \\
\text { to the task at hand }\end{array}$ \\
\hline $\begin{array}{c}\text { Information System } \\
\text { Success Model [22] }\end{array}$ & $\begin{array}{c}\text { Developed for evaluating Information } \\
\text { System Success }\end{array}$ \\
\hline Human Organization & A model tailored to evaluate Health \\
\hline
\end{tabular}

\section{Volume 6 Issue 7, July 2017}


International Journal of Science and Research (IJSR)

ISSN (Online): 2319-7064

Index Copernicus Value (2015): 78.96 | Impact Factor (2015): 6.391

\begin{tabular}{|c|c|}
\hline $\begin{array}{c}\text { Technology Fit } \\
\text { Model[23] }\end{array}$ & Information System \\
\hline $\begin{array}{c}\text { Integrated Acceptance } \\
\text { and Sustainability }\end{array}$ & Generic Model for evaluating \\
Assessment Model & Sustainability of a Technology \\
(IASAM) [24] & \\
\hline Design and Evaluation & $\begin{array}{c}\text { Designed to Evaluate Sustainability of } \\
\text { Framework for mHealth } \\
\text { [25] }\end{array}$ \\
\hline
\end{tabular}

\section{Problem Definition}

The disease burden in developing countries have made it necessary to adopted technology as strategies for tackling the challenge in order to lower the rising mortality and morbidity. Across many developing countries, mHealth solutions have been embraced but a significant number of the implemented mHealth solutions are reported to have failed after a short period of usage and the main reason cited is lack of sustainability. In order to establish the sustainability of an mHealth solution or system, a structured evaluation must be carried out; various tested parameters must be used to gauge and establish the sustainability of the mHealth solution. In the effort to develop a solution for the mHealth sustainability challenge, existing models must be assessed to determine their suitability to evaluate sustainability of the mHealth solutions in developing countries context.

\section{Methodology / Approach}

The study was carried out through six main steps:

- Review of literature to understand the growth and utilization of mHealth utilization in the developing countries context.

- Establishing the thematic areas of mHealth application in developing countries.

- Understand the success and failures of mHealth projects in developing countries and some of the reasons cited for failure.

- Review of literature to identifying sustainability challenges of mHealth system in the developing countries context.

- Analyze existing models and assess their suitability of existing models in evaluating sustainability of mHealth systems in the developing context.

- Make recommendations on the need for a more comprehensive model.

\section{Results \& Discussion}

Review of literature on the challenges of mHealth system and projects in developing countries reveals that a combination of human, technology and management factors contribute to failure of mHealth projects. Analysis of the existing technology evaluation model reveals that each has weaknesses and thus non is suitable for evaluating the mHealth systems sustainability in the developing countries context.
Table 2: Information System Success Model Information Systems success model [22]

\begin{tabular}{|c|c|c|}
\hline \multicolumn{3}{|c|}{ Information Systems success model [22] } \\
\hline $\begin{array}{c}\text { Constructs in } \\
\text { the model }\end{array}$ & $\begin{array}{l}\text { Strengths of the } \\
\text { model }\end{array}$ & Weakness of the model \\
\hline $\begin{array}{l}\text { System } \\
\text { Quality }\end{array}$ & $\begin{array}{l}\text { Designed to } \\
\text { assess and }\end{array}$ & $\begin{array}{l}\text { The weakness of this model is } \\
\text { that it does not explain whether }\end{array}$ \\
\hline $\begin{array}{c}\text { Information } \\
\text { Quality }\end{array}$ & $\begin{array}{l}\text { establish whether } \\
\text { a system is }\end{array}$ & $\begin{array}{l}\text { a successful system will } \\
\text { necessarily be sustainable. In }\end{array}$ \\
\hline $\begin{array}{l}\text { Service } \\
\text { Quality }\end{array}$ & $\begin{array}{l}\text { successful. It } \\
\text { capture }\end{array}$ & $\begin{array}{l}\text { addition, it is silent on the role } \\
\text { of management factors in the }\end{array}$ \\
\hline System Use & technological & success and sustainability of a \\
\hline $\begin{array}{c}\text { User } \\
\text { Satisfaction }\end{array}$ & $\begin{array}{c}\text { factors (System } \\
\text { Quality, }\end{array}$ & \\
\hline Net Benefits & $\begin{array}{l}\text { Quality) } \\
\text { Individual } \\
\text { Factors (System } \\
\text { Use, User } \\
\text { Satisfaction and } \\
\text { Service Quality) } \\
\text { and the outcome } \\
\text { of using the } \\
\text { system (Net } \\
\text { Benefits), } \\
\end{array}$ & $\begin{array}{l}\text { This model assumes a formal } \\
\text { environment where access is } \\
\text { guaranteed, which might not be } \\
\text { the case for mHealth systems in } \\
\text { developing countries. It is also } \\
\text { silent on role of Technology } \\
\text { Interoperability and Technology } \\
\text { scalability in the sustainability } \\
\text { of mHealth system. }\end{array}$ \\
\hline
\end{tabular}

Table 4: Task Technology Fit Model Task Technology Fit Model [21]

\begin{tabular}{|c|c|c|}
\hline \multicolumn{3}{|c|}{ Task Technology Fit Model [21] } \\
\hline $\begin{array}{c}\text { Constructs in } \\
\text { the model }\end{array}$ & $\begin{array}{l}\text { Strengths of the } \\
\text { model }\end{array}$ & Weakness of the model \\
\hline \begin{tabular}{|c|} 
Task \\
Requirements \\
\end{tabular} & \multirow{3}{*}{$\begin{array}{l}\text { Best suited to } \\
\text { evaluate how well } \\
\text { the technology } \\
\text { functional feature } \\
\text { map to the task at } \\
\text { hand }\end{array}$} & \multirow{3}{*}{$\begin{array}{l}\text { Fails to address the role of } \\
\text { individual factors and } \\
\text { management factors in the } \\
\text { sustainability: it fails to } \\
\text { state whether a technology } \\
\text { whose functional features } \\
\text { match the tasks at hand will } \\
\text { be sustainable }\end{array}$} \\
\hline \begin{tabular}{c|c|} 
Tool \\
Functionality \\
\end{tabular} & & \\
\hline $\begin{array}{c}\text { Task- } \\
\text { Technology } \\
\text { Fit }\end{array}$ & & \\
\hline
\end{tabular}

Table 3: Human-organization-technology fit Model Human-organization-technology fit (HOT-fit) [23]

\begin{tabular}{|c|c|c|}
\hline model & $\begin{array}{r}\text { Streng } \\
\mathrm{m} \\
\end{array}$ & Weakness \\
\hline & \multirow{8}{*}{\begin{tabular}{|} 
It is a powerful \\
model that was \\
designed \\
specifically to \\
evaluate Health \\
Information \\
Systems. It \\
highlights the \\
Human \\
(Individual), \\
Technology and \\
Organizational \\
factors that are key \\
in the evaluation of \\
healthcare \\
information \\
systems.
\end{tabular}} & \multirow{8}{*}{$\begin{array}{l}\text { The model assumes a } \\
\text { formal environment } \\
\text { where challenges of } \\
\text { accessing the model are } \\
\text { not experienced a } \\
\text { typical case for } \\
\text { mHealth solutions in } \\
\text { the developing; it is } \\
\text { silent on access issues. } \\
\text { Further, the model fails } \\
\text { to address the role of } \\
\text { technology } \\
\text { interoperability and } \\
\text { technology scalability } \\
\text { in the sustainability of } \\
\text { the mHealth systems in } \\
\text { the developing } \\
\text { countries context. }\end{array}$} \\
\hline $\begin{array}{l}\text { Informat } \\
\text { Quality }\end{array}$ & & \\
\hline Serv & & \\
\hline & & \\
\hline & & \\
\hline Net & & \\
\hline & & \\
\hline $\begin{array}{l}\text { Organiza } \\
\text { Environn }\end{array}$ & & \\
\hline
\end{tabular}

Table 5: Design \& Evaluation framework for mHealth

\begin{tabular}{|c|c|c|}
\hline \multicolumn{2}{|c|}{ Design \& Evaluation framework for mHealth [25] } \\
\hline $\begin{array}{c}\text { Constructs in the } \\
\text { model }\end{array}$ & Strengths of the model & $\begin{array}{c}\text { Weakness of the } \\
\text { model }\end{array}$ \\
\hline $\begin{array}{c}\text { Governance } \\
\text { Models }\end{array}$ & $\begin{array}{c}\text { The model is specifically } \\
\text { designed to evaluate mHealth } \\
\text { systems and it specifies four }\end{array}$ & $\begin{array}{c}\text { The } \\
\text { sustainability } \\
\text { phase in this }\end{array}$ \\
\hline Financing &
\end{tabular}

\section{Volume 6 Issue 7, July 2017} www.ijsr.net 


\section{International Journal of Science and Research (IJSR) \\ ISSN (Online): 2319-7064}

Index Copernicus Value (2015): 78.96 | Impact Factor (2015): 6.391

\begin{tabular}{|c|c|c|}
\hline Models & stages/phases of evaluation: & model fails to \\
\hline $\begin{array}{l}\text { Interoperability } \\
\text { Plan }\end{array}$ & $\begin{array}{l}\text { Design, Development, } \\
\text { Implementation and }\end{array}$ & $\begin{array}{c}\text { address the role } \\
\text { of system }\end{array}$ \\
\hline $\begin{array}{l}\text { Privacy and } \\
\text { Compliance } \\
\text { Plan }\end{array}$ & $\begin{array}{c}\text { Sustainability. It further } \\
\text { specifies what need to be } \\
\text { evaluated when attempting to }\end{array}$ & $\begin{array}{c}\text { quality, system } \\
\text { support, Access } \\
\text { to the system, }\end{array}$ \\
\hline $\begin{array}{l}\text { Outcome } \\
\text { measurements }\end{array}$ & $\begin{array}{l}\text { establish the sustainability of } \\
\text { an mHealth system. It clearly }\end{array}$ & $\begin{array}{c}\text { user satisfaction, } \\
\text { system }\end{array}$ \\
\hline $\begin{array}{l}\text { Return on } \\
\text { Investment }\end{array}$ & $\begin{array}{c}\text { points factors that are critical } \\
\text { to sustainability; Return on } \\
\text { Investment, Financing, } \\
\text { Outcome of System Use, } \\
\text { Interoperability plan, } \\
\text { Governance models and } \\
\text { security (privacy and } \\
\text { compliance) }\end{array}$ & $\begin{array}{l}\text { scalability and } \\
\text { system } \\
\text { interoperability. }\end{array}$ \\
\hline
\end{tabular}

Table 6: Integrated Acceptance and Sustainability Assessment Model

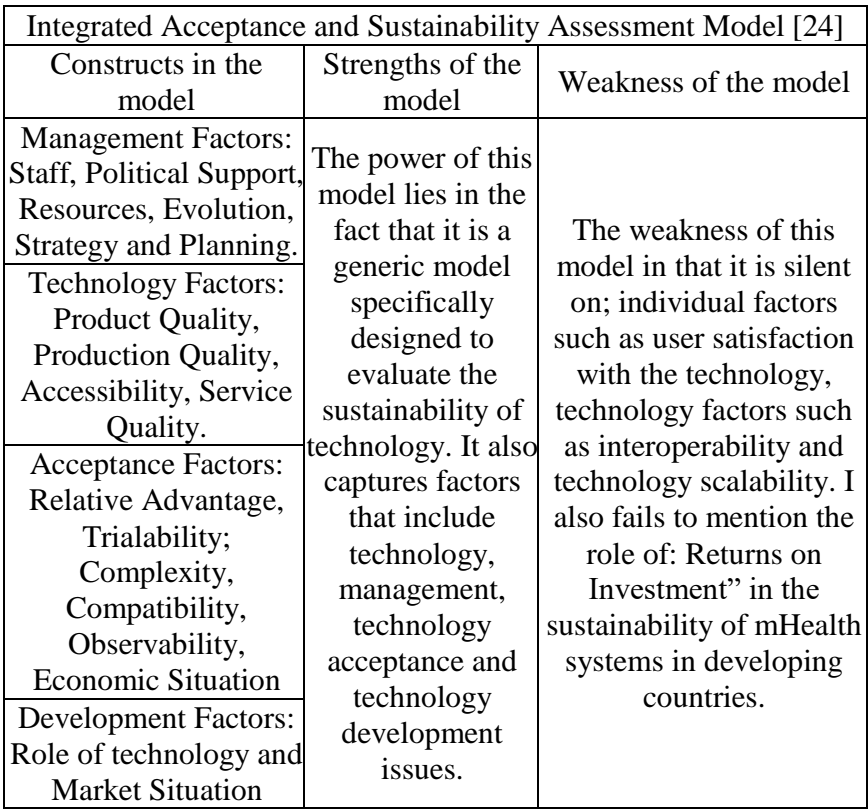

\section{Conclusion}

The mHealth strategy for tackling disease burden provides a promising alternative strategy that could aid in lowering morbidity and mortality in developing countries. Failed mHealth systems slow down the fight against the disease menace. Sustainable solutions would greatly contribute to the efforts of tackling the disease challenge. Structure evaluation to establish the sustainability of implemented mHealth system in necessary and the current model have significant weakness hence not suitable. There is an urgent need to develop and validate a comprehensive model for evaluating sustainability of mHealth systems in development countries.

\section{Future Scope}

The future research will focus on developing and validating a comprehensive model for evaluating sustainability of mHealth system in developing countries context. The research will be carried out under the following steps; identifying factors that should be considered when evaluating sustainability of mHealth systems, designing a model for evaluating sustainability of mHealth systems and validating the model in the

\section{References}

[1] WHO (2013) Call for innovative health technologies. http://www.who.int/ehealth/en/. Accessed 15 January 2015.

[2] WHO 2011c, mHealth: New horizons for health through mobile technologies, WHO, Geneva.

[3] Vital Wave Consulting, (2009). Health Information Systems in Developing Countries: A Landscape Analysis

[4] Muhambe T. and Orwa D. (2015) Tackling the Disease Burden: A Case for mHealth in Kenya. Journal of Emerging Trends in Computing and Information Sciences. Vol. 6, No. 8, August 2015

[5] Zurovac et al., (2011), Raymond K Sudoi, Willis S Akhwale, Moses Ndiritu, Davidson H Hamer, Alexander K Rowe, Robert W Snow (2011) Kenyan health workers' adherence to malaria treatment guidelines: a cluster randomised trial. www.thelancet.com Published online August 4, 2011.

[6] Gold et al., (2012) Using mobile phone text messages (SMS) to collect health service data: Lessons from social franchises in Kenya, Madagascar and the Philippines. Journal of Health Informatics in Developing Countries Vol. 6 No. 2, 2012 www.jhidc.org (Accessed July 2016)

[7] West, D. (2012). How mobile devices are transforming healthcare. Issues in Technology Innovation, 18, 14.

[8] Déglise C, Suggs LS, Odermatt P. Short message service (SMS) applications for disease prevention in developing countries. J Med Internet Res 2012;14(1):e3 [FREE Full text] [doi: 10.2196/jmir.1823]

[9] Chigona, Wallace., Mphatso Nyemba-Mudenda., Metfula, Andile Simphiwe (2013). A review on mHealth research in developing countries. The Journal of Community Informatics Vol 9, No 2 (2013)

[10] QuintanaY. m-Health Design and Evaluation. Mobile World Congress. 2015.

[11] Smith C. Vannak, U. Sokhey L. Cockroft M. Overcoming mHealth Operational Challenges in Cambodia (RE: JMTM 2013, 2: 20_23)

[12] Brundtland, Gro Harlem (1987). Report of the World Commission on Environment and Development: Our Common Future. Oslo, 20 March 1987

[13] Land, F.F., (2000), Evaluation in a Socio-Technical Context

[14] Aggarwal Y. P. (2008),Science of Educational Research, Nirmal Book Agency.

[15] Cherns, A., (1976), The Principles of Sociotechnical Design, Human Relations, Vol.2, No. 9, pp 783-792

[16] Avgerou, C., Ciborra, C. and Land, F.F., editors, (2004), The Social Study of Information and Communications Technology: Innovation, Actors and Context, Oxford, OUP

\section{Volume 6 Issue 7, July 2017 www.ijsr.net}




\section{International Journal of Science and Research (IJSR) \\ ISSN (Online): 2319-7064}

Index Copernicus Value (2015): 78.96 | Impact Factor (2015): 6.391

[17]Clegg, C.W., (2000), Sociotechnical Principles for Systems Design, Applied Ergonomics, Vol. 31, pp 463477

[18] Sawyer, S., and Jarrahi, M. H. (2014). Sociotechnical Approaches to the Study of Information Systems

[19] Heller, F. (1997) Sociotechnology and the Environment, Human Relations, Vol. 50, No 5, pp. 605-624

[20] Bostrom, R. P., \& Heinen, J. S., (1977). MIS problems and failures: A socio-technical perspective, MIS Quarterly, Vol. 1, No. 3, pp. 17-32

[21] Goodhue, D.L. and Thompson, R.L. (1995). Tasktechnology and individual performance, MIS Quarterly 19(2), 1995, pp. 213-236.

[22] DeLone, W.H. and McLean, E.R., (2004) Measuring ecommerce success: applying the DeLone \& McLean Information Systems Success Model, Int. J. Electron. Commerce 9 (1) (2004) 31-47.

[23] Maryati Mohd Yusof, Jasna Kuljis, Anastasia Papazafeiropoulou, Lampros K Stergioulas (2008). An evaluation framework for Health Information Systems: human, organization and technology-fit factors (HOTfit). International journal of medical informatics. Volume 77(6) 386-398. Elsevier

[24] Aizstrautaa D, Gintersa E, Eroles MP. Applying Theory of Diffusion of Innovations to Evaluate Technology Acceptance and Sustainability. ICTE in Regional Development, December 2014, Valmiera, Latvia. Procedia Computer Science 43 (2015 ) 69 - 77. www.sciencedirect.com

\section{Author Profile}

Muhambe Titus Mukisa Holds an MSc in Information Systems from University if Nairobi and currently afinalizing $\mathrm{PhD}$ candidate at the School of Computing and Informatics of the University of Nairobi, specializing in health Informatics. Research interests include; ICT for Development and Information system design, development, development, evaluation and Audit.

Daniel Orwa Ochieng holds a Doctoral Degree in Information Systems, is currently a Senior Lecturer in School of Computing and Informatics and an Experienced researcher in ICT for development; focusing on Agriculture, health and education. Prolific author and reviewer in several reputable international journals in the areas of information system and ICT for development.

Peter Wagacha Waiganjo hold a $\mathrm{PhD}$ in computer science and is currently Professor of Computer Science in the School of Computing of the University of Nairobi and researcher in ICT for development.Research interests covers artificial intelligence, machine learning, ICT for development. Also an author and reviewer in several reputable international computer science journals. 